\title{
Editorial
}

\section{Where the Action is}

\section{WENDY HARCOURT}

The last Development issue was on the Millennium Development Goals (MDG). Since then the Millennium Project Report headed by Jeffrey Sachs has been released, which has made a valiant effort to broaden the narrow scope of the time-bound goals, targets and indicators. Most of the task forces have taken an openly political and human rights approach in critiquing systemic inequalities, asking for an expansion of the indicators and naming the economic and political power bases that underline world poverty. On the other side of the Atlantic, the recent report of the Blair Commission on Africa seems also to herald a more open discussion on underlying systemic inequalities. It unflinchingly points to how global inequality is distorting African development, as the billions looted from the African continent and its people line the pockets of the West and a tiny African elite. It is not afraid to state that this global level corruption is compounded by the privatization of military power and the globalization of financial services, which enable the scams and theft to continue unabated.

These welcome and influential reports could well make us question the tenor of the MDG Journal issue. Is it, after all, possible that the UN will shore up multilateralism and establish a strong human development and rights agenda in the face of unilateralism and the war on terror? Will Tony Blair as head of the G8 be able to take to task the US-dominated financial centres and private military interests? Are we seeing finally a questioning of the world's embrace of neo-liberal market policy? Is there going to be a new era that tackles systemic inequalities in order to 'make poverty history'?

One can hope, but in the same period we see disturbing signs of US conservatism happily riding rough shod over any progressive ideas. The Bush administration's appointment of Paul Wolfowitz as President of the World Bank, will as Development Associate Editor Sanjay Reddy states, do enormous damage. Both in academia and in government, Paul Wolfowitz has been a relentless exponent of the US national interest and one can hardly expect him to further the collective interest of the world's poor. Two other top conservative appointments are equally disconcerting. Ann Veneman, former US Secretary of Agriculture is Executive Director of UNICEF from May 2005. She has been a key advocate for agribusiness, both as a private lawyer and in government and has no previous knowledge of child rights. The appointment of John Bolton, an outspoken long-time critic of the United Nations as US ambassador to the UN dents even further the world community's confidence in the Bush administration. 
I have just returned from the 49th Commission on the Status of Women in New York where 3,000 women from civil society joined government and UN bureaucrats in defense of the Beijing Platform of Action agreed to ten years ago. I can only confirm that US conservatism and arrogance is much in evidence. In the basements of the UN, one full week of the Commission was wasted in fighting the US just to ensure that the ten-year-old agreement was ratified. The US finally bowed to pressure, and the next week was taken up with challenging two US-proposed resolutions on trafficking and women and economic advancement.

It was a trying time to see how the US delegation was so arrogantly using the UN platform to appease its domestic political base. It was frankly a dispiriting waste of energy for all involved, those on the delegations, civil society activists and UN staff. People were holding on grimly to keep decade-old promises, rather than pushing on with strategies that would ensure the resources and capacity to put the Platform into action.

It must be said that the MDG agenda also hung like a cloud over the proceedings. On podiums and in petitions, senior women were asking the Secretary General and governments to ensure that the Beijing promises would be reaffirmed in the review of the Millennium Declaration due September 2005. One had to wonder about the efficiency of UN mechanisms when so many speeches had to make the links between two UN documents - the Beijing Platform and the Millennium Summit Declaration. Why was it so necessary to plea that gender equality and women's human rights are (this time?) integrated into the development agenda? Similarly, the corridors were abuzz with whether Kofi Annan will take up sexual and reproductive health and rights as a new MDG target - an agenda already agreed to in Cairo in 1994 but somehow misplaced in the MDG goals. Even if sexual and reproductive rights were to be reinstated, it was clearly not going to stop the arrogance and bully boy tactics of the US with its well-heeled and loud-mouthed anti-reproductive rights agenda.

So if one had stayed in the basement and hovered around the General Assembly rooms and it might well have seemed that there is little to be hopeful about, particularly as the haggling around the resolutions meant the meeting could not be concluded. However, if one surfaced and headed up a dozen or so floors into the UN Secretariat, there were some other interesting discussions going on. Mark Malloch Brown, once head of UNDP, now Kofi Annan's Chief of Staff was talking to the new people on the scene - the Porto Alegre social movement representatives who were invited to discuss with him their interest in UN Reform, following the World Social Forum launch by Lula with 15,000 people present. In a jovial mode, he apparently disparaged the old NGOs' and looked eagerly to working more closely with the World Social Forum protagonists.

And if one moved downtown to SoHo, there were international women's groups coming together for a dance party to mark their support for the Global Call to Action against Poverty (GCAP). Distributing white bandanas, a woman's adaptation of the white bands to be worn 1 July when leaders of the G8 countries meet in Scotland, hundreds of women celebrated and planned. They were joining the thousands around the world (including the highly publicized Trafalgar Square event addressed by Nelson Mandela) in the call to end poverty. On 8 March, Women's International Day Code Pink mobilized US and international women's groups to march from Time Square to the UN in protest against the Iraq War. Strategy meetings well outside the UN brought trade unions, faith organizations, reproductive rights groups, alternative globalization groups, development NGOs and women's human rights groups to debate where the women's movement needed to put their energy. Many had come to New York to defend Beijing, and to show the world that women's rights continue to be important, but the real excitement and energy was beyond the UN halls with its dismal bureaucracy and confusing rules around scraps of text. Instead the vision and tough talking about how to tackle the economic, political and moral agenda that had betrayed the promises of Beijing were to be heard in the strategy meetings among those who had participated in the feminist dialogues of the World Social Forum, and other regional Forums around the world. 
It was in those hard-headed realistic talks, in between the marching, dancing and forays to the UN basement that one could see where the women's movement is heading. The UN and the fight against the US forces bent on destroying it may be one site for action. But there are now many other sites where the struggle for global justice, rights and solving world inequalities are happening. The UN with its cumbersome way of working, however much it speaks about reform, and however well it can sell its MDG strategy, no longer seems to be where the action is happening.

The new forms of dialoguing, organizing, negotiating, networking and moving belong to the global justice movements, the new-global, altermondialiste, or Globalisierungskritiker born out of profound dissatisfaction of the post Seattle era and as an expression of discontent after the UN Conferences of the 1990s.

This edition of Development continues the discussion of earlier journal issues by inviting those contributing to the shaping of those political spaces to share with readers the history, the events, the process, the challenges and the future of the 'movement of movements'. Associate editor Nicola Bullard has put together a fascinating set of articles that take us to the heart of the action.

The articles show that the Social Forum process is the meeting place for progressive movements and organizations. Christophe Aguiton gives an insider's sketch of the movements joining forces globally with a history and considered discussion of why so trade unions, youth movements, women's movements, peace activists, environmentalists, NGOs in the South and many others are coming together to fight neo-liberal market forces. Others like Atilio Boron, Peter Rosset, Peter
Waterman, Virginia Vargas, Rochelle Jones, Salma Maoulidi and Peter Wahl describe from their regional and specific entry points how the old and new are merging into something quite different in the Forum process. Michal Osterweil, Boaventura de Sousa, Rajeev Patel and João Pedro Stedile theorize on what is making this process so transformatory and so exciting. The insider differences are shared by Shalmali Guttal, Massimo De Angelis and Roberto Savio who from diverse positions give a selfcritical reflection on the actual forum organizing process. Others like Katharina Mouratidi, Linda Milazzo, Anita Anand and Gemma Galdon from Babels celebrate the sense of innovation and hope as so many people come together to tackle the major economic, social and military powers and in the process find new ways to build consensus across localities. Throughout the articles one is continually struck by the seriousness of the selfreflections, the enormity of the task and also the sense of hope that it can be, indeed is being achieved.

In comparing the two issues, we can see that the Forum process is exposing many of the old, tired and disillusioned ways of the UN. The fact that so many people of all ages are mobilized through the movements to go out on the streets, to strike, to protest against war, to express themselves through political action, speaks for itself. The articles resonate with an honesty that cuts through the cynicism that marked much of the MDG journal. In this journal, there is not the search for leaders, nor for blue prints and measurements, but for ways to work with diversities, to celebrate and to put into place new, different visions of global social justice that go beyond old hegemonies and old orders. 